\title{
Destination brand equity in tourism context: evidence on Iran
}

DOI 10.1515/ejthr-2016-0020

received 15 December, 2015; accepted 10 October, 2016

Abstract: Tourism industry provides an important source of income for many countries; it has been considered the second important industry of the 21st century. This study analyses the effect of destination brand equity on tourists' intention to revisit. Kish Island was chosen for this case study. Components of destination brand equity include destination awareness, destination image, destination quality, perceived value, destination loyalty, satisfaction and intentions to revisit. This research is a descriptive and survey study. The target population was travelers who visited this island in the first half of 2013. The questionnaire was the research tool. Data were analysed using SPSS and LISREL. The results showed that there is a meaningful relationship between the destination awareness and perceived value, image destination and perceived value and satisfaction, destination quality and perceived value and destination loyalty, perceived value and destination loyalty, satisfaction and destination loyalty and intentions to revisit, and finally destination loyalty and intentions to revisit.

Keywords: Destination brand equity; Intention to revisit; Tourists' evaluations

\footnotetext{
*Corresponding author: Masoud Lajevardi, Department of Management, Shahmirzad Branch, Islamic Azad University, Shahmirzad, Iran, Tel: (+98) 9125318300, E-mail: lajevardi_masoud@yahoo.com Bahram Kheiri, Mehdi Mohsenipoor Golmaghani, Department of Management, Central Tehran Branch, Islamic Azad University, Tehran, Iran

Sina Fakharmanesh, Seyyedeh Sahar Mousavi, Department of Management, Shahid Beheshti University, Tehran, Iran
}

\section{Introduction}

Tourism industry has been an important source of income for many countries; it has been considered the second important industry of the 21st century [17]. For this reason, it is necessary to find reasonable ways and come up with a disciplined plan to achieve a higher share in world market. Tourism is among the few businesses in which evidences of production and service in plans related to attraction, maintenance and extension are easily observable [12]. In the countries that rely much on tourism industry, it stands at the top of all other industries as a green and non-polluting industry because it fits cultural, sociological, political and environmental conditions of these countries and also gives high returns [4]. Although the concept of destination has attracted the attention of many researchers working in the fields of marketing and tourism management, academic and disciplined researches on this subject are relatively few [2]. Some articles written about destination brand have not gone beyond conceptual research. Measuring the effectiveness of such brands is of high importance and can be determined using customer-based studies [10].

Blain et al., while focusing on the measurement of destination brands, give no empirical evidence on this aspect and have used direct approach to measure customer-based brands. Customers regard a destination as a conceptual notion, which can be interpreted subjectively and through experience [12]. If a powerful and stable experience of destination is formed in tourists' minds and managed correctly, it would create the foundation of a destination brand [21]. Destinations offer a combination of goods and services that are referred to as destination brands [19]. Destination marketing aims to increase the knowledge of tourists of the destination through making it a unique brand [24]. What determines a tourist's choice is his understanding of the destination. Understanding of the market or tourists' opinion are affected by appropriate or inappropriate advertisements and market or tourists' experiences, knowledge and awareness [32]. Managers 
of destinations are expected to review images held by each sector of the market about the destination and take necessary actions to keep or develop those images [29]. Destination loyalty is defined as the attachment that a customer has to a brand or as a deeply held commitment to rebuy or repatronise a preferred product or service consistently in the future [23]. Mangers of tourist regions should know what sectors attract tourists' attention and interest more because creating loyalty and attraction as a way of ensuring tourists' revisit is very difficult [10, 14]. Iran ranks approximately one-hundredth among countries and attracts only one million tourists. Experts believe that if Iran attracts 12 million tourists in a year, the revenue gained from each tourist is equal to the value of dozens of oil drums with the consequence that revenues of tourism industry will replace that of oil industry [2]. It can be concluded from the above discussions that development of tourism industry is of economical and socio-cultural importance for all countries, including Iran. The purpose of the current study is to propose and test a model for determining the effect of destination brand equity on the intention to revisit.

\section{Literature Review}

Following concepts introduced by Aaker (1991) and Keller (1993), Konecnik and Gartner (2007) are possibly among the first researchers who have addressed customer-based brand equity for a destination $[1,5]$. Their survey was a questionnaire that had 32 questions, all based on previous researches about destination image. They used this tool to measure Slovenian brand equity among German and Croat tourists. Their aim was to offer a model of destination brand equity and test whether components of brand equity (such as awareness, destination image, destination quality and destination loyalty), which are adopted from marketing literature, are valid to be used for measuring brand equity or not. Konecnik and Gartner considered brand as an indicator. When tourists hear a brand, it creates mental images of that destination. These images have four dimensions: destination brand awareness, destination image, destination experience and destination loyalty [13].

Boo et al. started a research about customer-based brand equity. While Konecnik and Gartner (2007) aimed to test the validity of four dimensions of brand equity, Boo et al. hypothesised that destination brand equity has five dimensions: destination brand awareness, destination image, destination quality, indicator value and destination loyalty. They didn't consider brand association as a dimension of brand equity. Boo et al. regarded the first three dimensions as the outward-driven variables that affect visitors' perceptions of brand equity. They also introduced an inward-driven variable called 'equity for money'. Following destination image, they believed that this is a different multidimensional notion for creating brand equity, which includes product specifications, brand personality and self-concept; however, they disagreed on the way to measure it [11].

In another study carried out by Marino et al. (2008) titled 'Customer relations and brand equity in banking industry', the goal was an exploratory study for determining an elementary understanding of customer relations, brand equity dimensions and the relationship between the two [20].

The study 'Destination Branding: Making India relevant and competitive in uncertain environment' was done by Balaji Venkatachalam and R. N. Venkateswaran in 2010. The purpose of the paper was to draw together the salient issues surrounding India as a destination brand under uncertainty into a single coherent discussion. The paper concludes with practical implications for destination marketer in India. The success of countries such Australia, France and Italy shows that destination can become brands that are contemporary and timeless [13].

Cui (2011) performed a research titled as 'Creating customer-based equity in the Chinese sports shoes market: Measurement, challenges and opportunities'. The method adopted in this study was quantitative. A total of 84 Chinese respondents between 21 and 36 years evaluated five brands of sport shoes. The results showed that four dimensions of brand quality (brand awareness, brand loyalty, perceived quality and brand image) have significant effects on brand equity; store image have positive influence on brand equity dimensions, whereas celebrity endorsement has no influence on brand equity dimensions [33].

Still in another study by Klara Trošt, Sara Klarić, and Marinela Dropulić Ružić titled 'Events as a framework for tourist destination branding: Case studies of two cultural events in Croatia' done in 2012, the focus of research is on tourist destination branding by means of events. The relationship between events and destination branding is examined through six phases of the process of building a destination brand identity with the use of events. When it comes to destination branding, a need for an analysis of strategic documents of destination development is required because event tourism strategies help destinations plan how to use events in a tourism role [34]. 
Mohammad Hossein Imani Khoshkhu and Hamid Ayubbi Yazdi (2011) in a paper titled 'Factors affecting destination brand equity of Yazd', while considering cultural and sociological differences and specific features of Iranian destinations, focus on domestic visitors' assessments of Yazd brand equity using Konecnik's model (2007). The results showed that in addition to brand image - regarded as the most important factor of brand equity assessment in studies done in last 30 years - brand loyalty, perceived quality and destination awareness also directly affect band equity of Yazd; as regards importance, brand loyalty was the most effective factor [2].

Accordingly, having reviewed related literature, the conceptual model of this study is presented in the Figure 1:

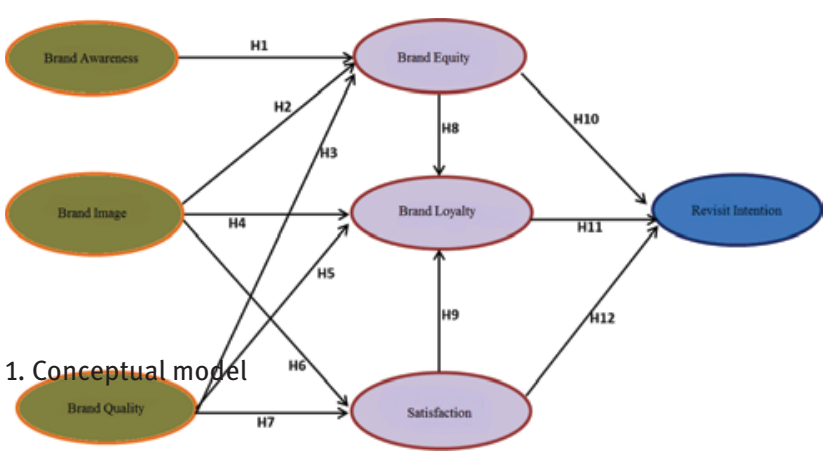

The current study consists of 12 hypotheses formed based on the conceptual model of the research.

H1. Destination brand awareness will positively and meaningfully affect brand equity.

H2. Brand image will positively and meaningfully affect brand equity.

H3. Brand quality will positively and meaningfully affect brand equity.

H4. Brand image will positively and meaningfully affect brand loyalty.

H5. Brand quality will positively and meaningfully affect brand loyalty.

H6. Brand image will positively and meaningfully affect satisfaction.

H7. Brand quality will positively and meaningfully affect satisfaction.

H8. Brand equity will positively and meaningfully affect brand loyalty.

H9. Satisfaction will positively and meaningfully affect brand loyalty.

H10. Brand equity will positively and meaningfully affect the intention to revisit.

H11. Brand loyalty will positively and meaningfully affect the intention to revisit.

H12. Satisfaction will positively and meaningfully affect the intention to revisit.

\section{Methodology}

This research is a descriptive and survey study and has a practical purpose. Structural equation modelling (SEM) was adopted to examine the relationship between the components of the model. Structural equation modelling is a statistical method that provides an understanding of multi-dimensional nature of the destination brand [3]. Structural equation modelling is necessary for the evaluation of marketing theories in that due to inevitable measurement errors, it is difficult to operationalise theoretical structures. Additionally, owing to the complexity of evaluation of destination brand and the lack of suitable measurement tools for destination brand equity, structural equations present an organised way in which certain causal relationships are established among the observed variables of the destination brand. Structural equation model is a technique for estimating and evaluating models of linear relations among a set of observed variables, while the number of latent variables is fewer [3].

LISREL model was used in this study to estimate the structural equation modelling. The study was carried out in the summer of 2013 in Kish Island. In formulating the research hypotheses destination awareness, brand image and brand quality are independent variables, intention to revisit is a dependent variable, and brand equity, brand loyalty, and satisfaction are moderator variables. The target population was chosen among the visitors who travelled to Kish Island in 2013. These participants were selected through a simple random sampling technique. As for the sample size, Cochran's formula of infinite sample size was adopted.

\section{$n=\frac{z^{2} \alpha / 2 \times p \times q}{\varepsilon^{2}}=\frac{(1.96)^{2} \times 0.5 \times 0.5}{(0.05)^{2}}=384$}

Therefore, the sample size of this study is 384 . Questionnaire is the instrument used for gathering data. Content validity was used to test the validity of the questionnaire. Content validity consists in experts' subjective judgments regarding the appropriateness of measurements. Cronbach's coefficient alpha was adopted for the final confirmation of the questionnaire.

The mean of Cronbach's coefficient alpha obtained for all of the research variables is above 0.7 , which is an indication of favorable validity of the questionnaire. 
Table 1: Cronbach's coefficient alpha for research variables

\begin{tabular}{ll}
\hline Research variables & Cronbach's alpha \\
\hline Destination awareness & 0.772 \\
Brand image & 0.707 \\
Brand quality & 0.713 \\
Brand equity & 0.776 \\
Brand loyalty & 0.750 \\
Satisfaction & 0.776 \\
Intention to revisit & 0.727 \\
\hline
\end{tabular}

\section{Findings}

\subsection{Testing the Normality of Distribution}

Examining research hypotheses requires an examination of normality of distribution among variables. So normality was examined using Kolmogorov-Smirnov test (Table 2).

Due to the fact the meaningfulness of KolmogorovSmirnov test in the above table is more than 0.05 for each variable, it is concluded that distribution of these variables is not meaningfully different from normal distribution; therefore, research variables are normally distributed.

\subsection{Factor Analysis}

Using the model of standardised coefficients, we can claim that there is a meaningful correlation between latent variables and their corresponding indicators.
Standardised coefficients are, in fact, path coefficients or standardised factor loadings and indicators. Validity is achieved when there is a meaningful correlation between factor and dimension, and between dimension and indicator. Standard estimation model is formed when two covariance matrixes are coincided and which shows real estimation of parameters of the model. The correlation between factor and dimension, and between dimension and indicator, is illustrated in this model. If the correlation is higher than 0.3 , questions are appropriately specified. As it can be seen, the indicators considered for the questions related to variables have a factor loading of over 0.3. In the rest of this paper, the factor analysis of each variable is presented separately and coefficients and indicators of closeness of the model are finally explained.

\subsubsection{Factor Analysis of Destination Awareness}

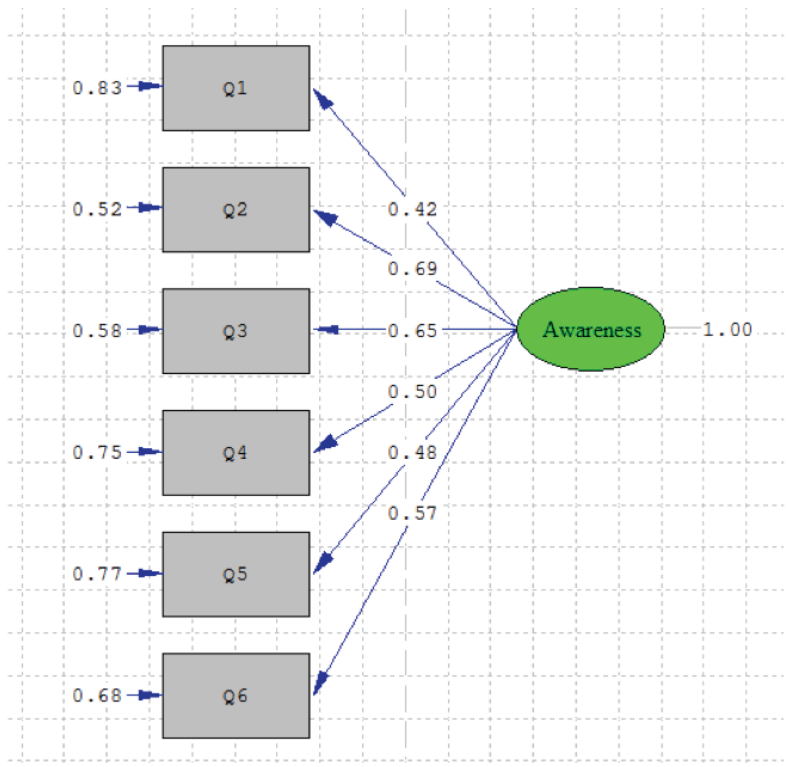

Figure 1: Standard model of destination awareness

Table 2: Kolmogorov-Smirnov test for determining the normal distribution among research variables.

\begin{tabular}{|c|c|c|c|c|c|}
\hline Variables & Number & Mean & Standard Deviation & Kolmogorov-Smirnov & P-value \\
\hline Destination awareness & 384 & 23.18 & 3.00 & 2.689 & 0.245 \\
\hline Brand image & 384 & 14.97 & 2.45 & 1.906 & 0.357 \\
\hline Brand quality & 384 & 9.6 & 2.13 & 2.695 & 0.124 \\
\hline Brand equity & 384 & 15.63 & 2.35 & 2.42 & 0.235 \\
\hline Brand loyalty & 384 & 21.11 & 3.56 & 1.772 & 0.142 \\
\hline Satisfaction & 384 & 18.3 & 2.88 & 1.583 & 0.313 \\
\hline Intention to revisit & 384 & 13.72 & 2.33 & 1.969 & 0.115 \\
\hline
\end{tabular}




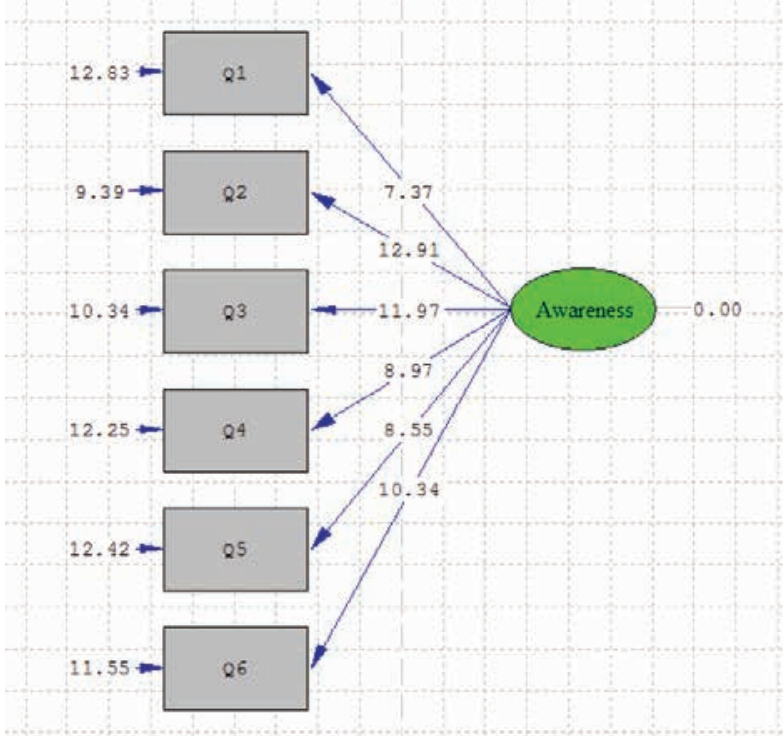

Figure 2: Meaningfulness of relationships of questions regarding destination awareness

\subsubsection{Factor Analysis of Brand Image}

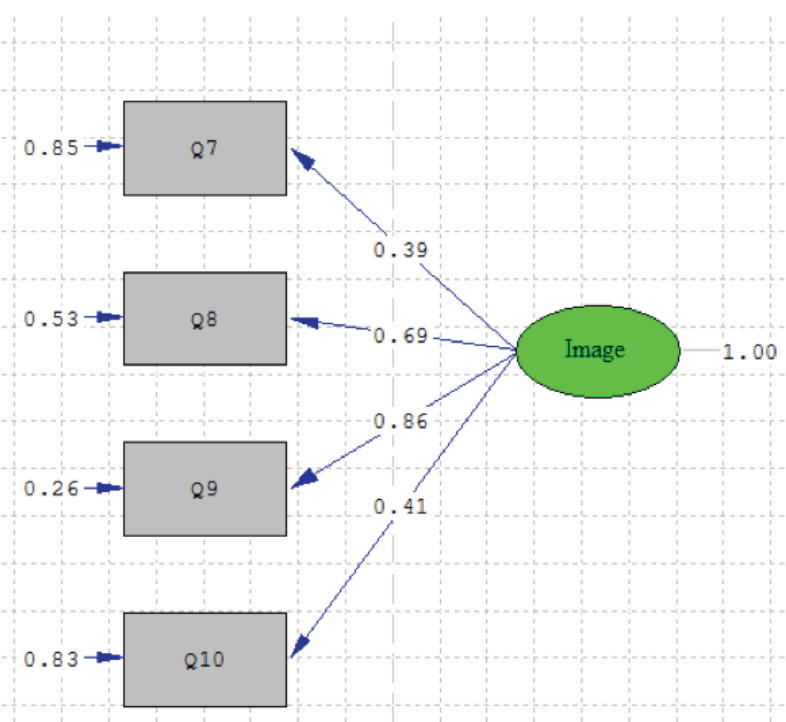

Figure 3: Standard model of brand image

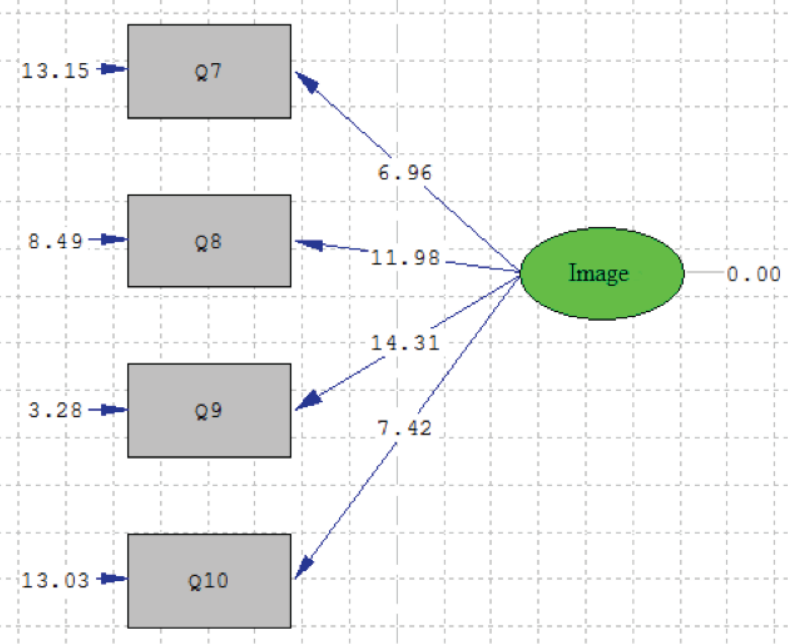

Figure 4: Meaningfulness of relationships of questions regarding brand image

\subsubsection{Factor Analysis of Brand Quality}

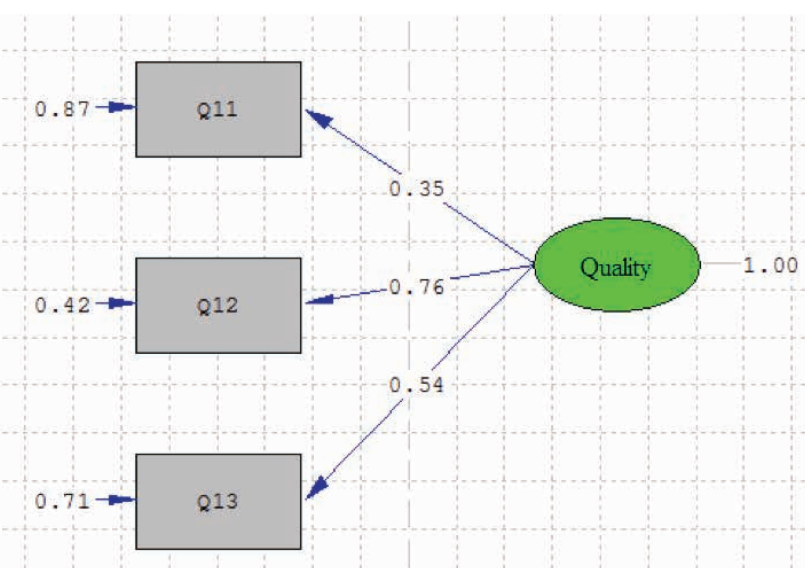

Figure 5: Standard model of brand quality

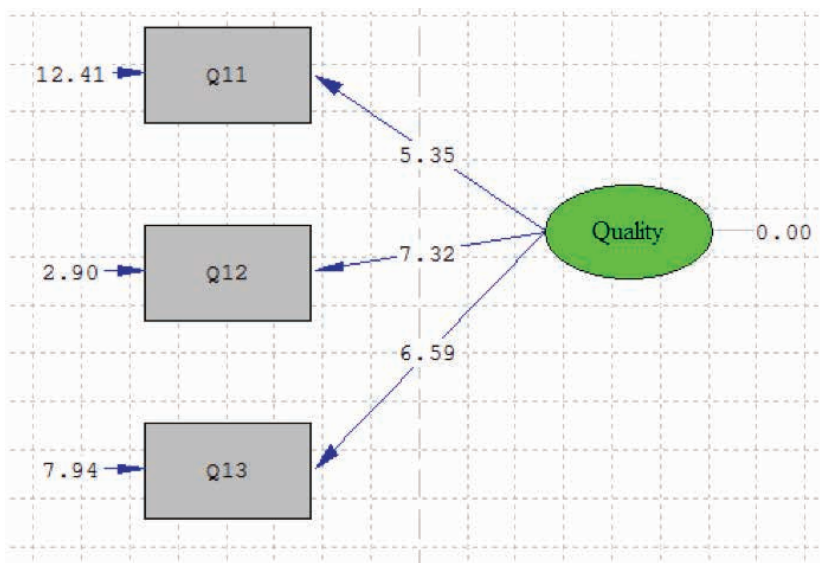

Figure 6: Meaningfulness of relationships of questions regarding brand quality 


\subsubsection{Factor Analysis of Brand Equity}

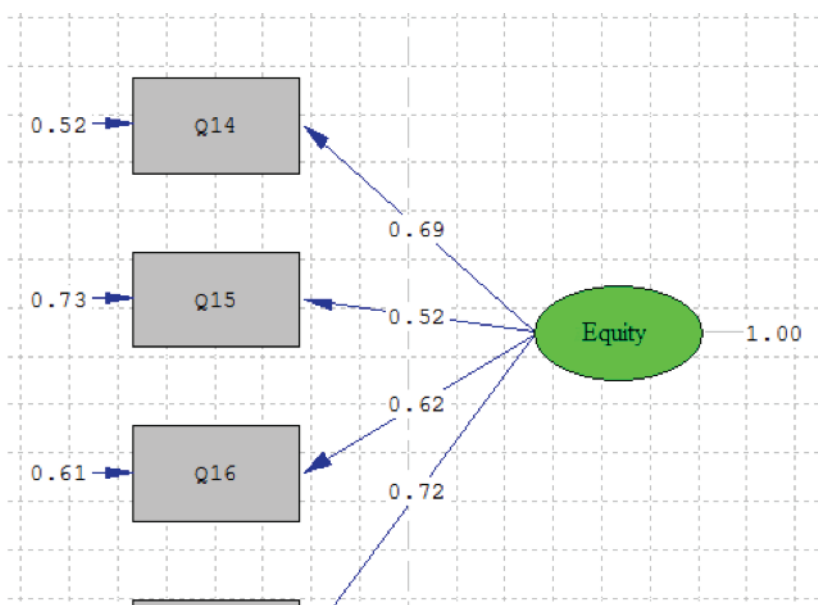

Figure 7: Standard model of brand equity

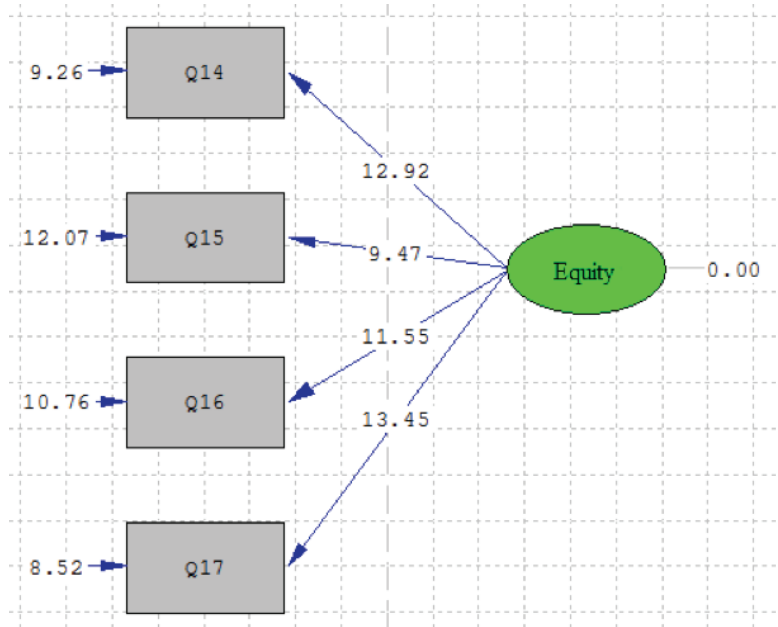

Figure 8: Meaningfulness of relationships of questions regarding brand equity

\subsubsection{Factor Analysis of Brand Loyalty}

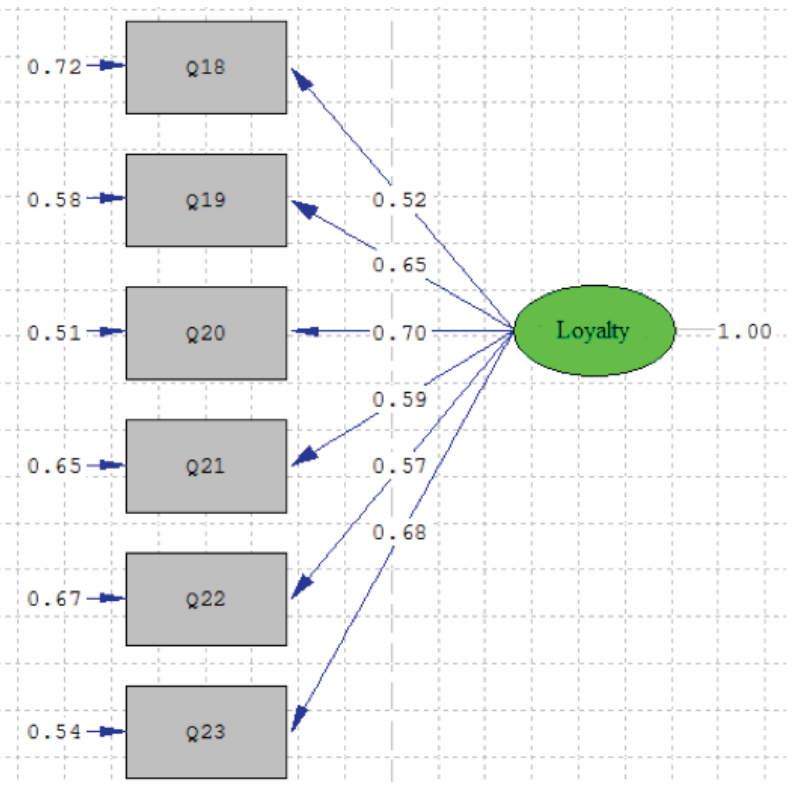

Figure 9: Standard model of brand loyalty

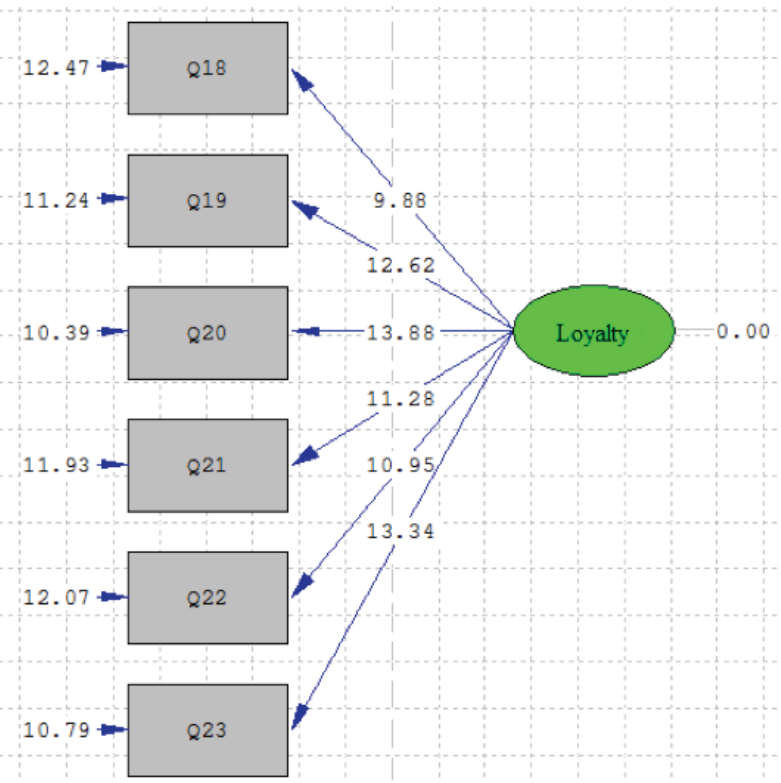

Figure 10: Meaningfulness of relationships of questions regarding brand loyalty 


\subsubsection{Factor Analysis of Satisfaction}

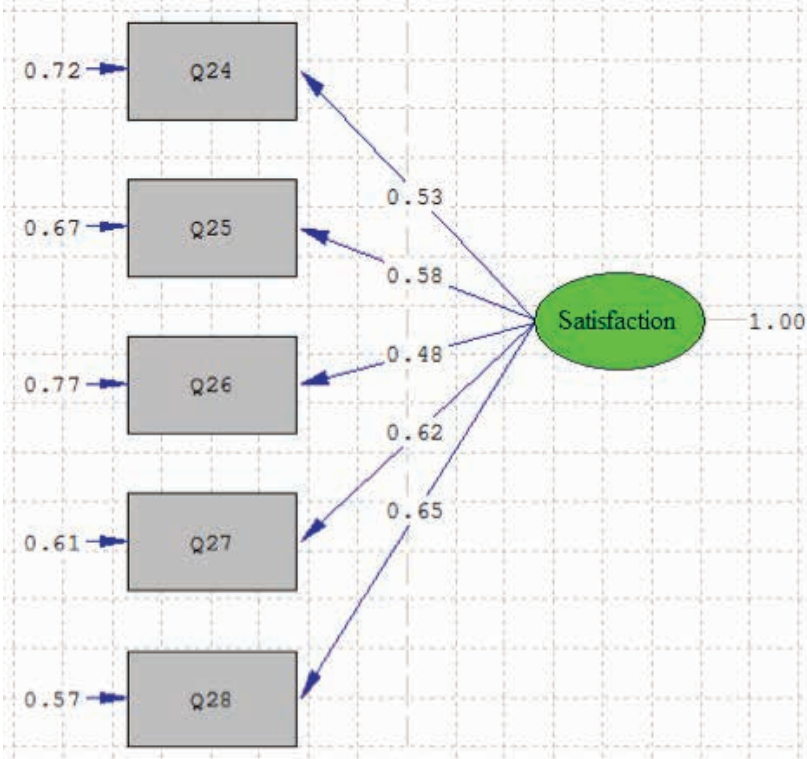

Figure 11: Standard model of satisfaction

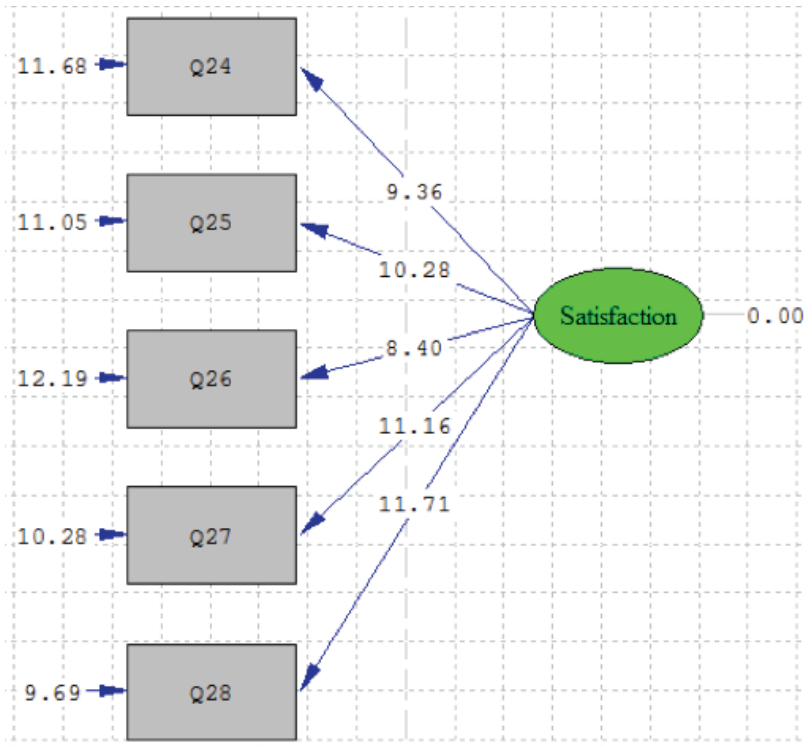

Figure 12: Meaningfulness of relationships of questions regarding brand satisfaction

\subsubsection{Factor Analysis of Intention to Revisit}

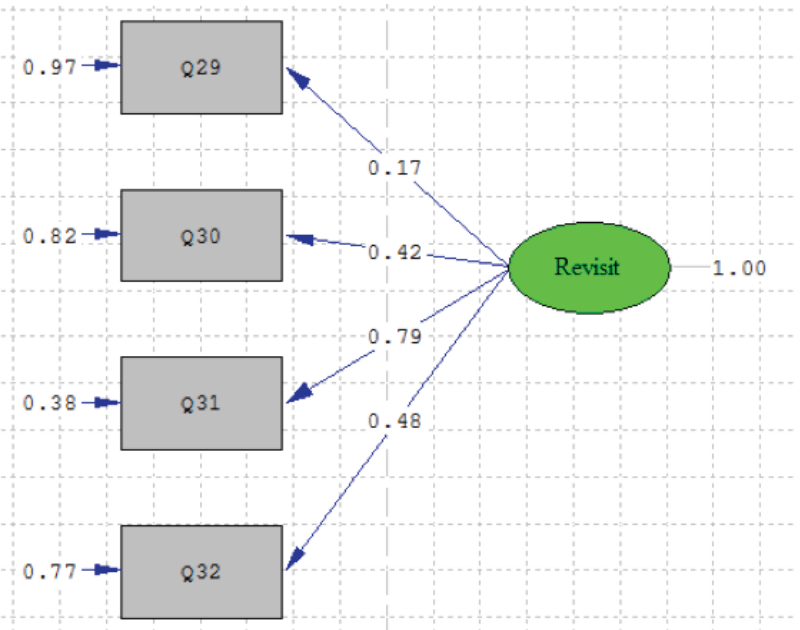

Figure 13: Standard model of intention to revisit

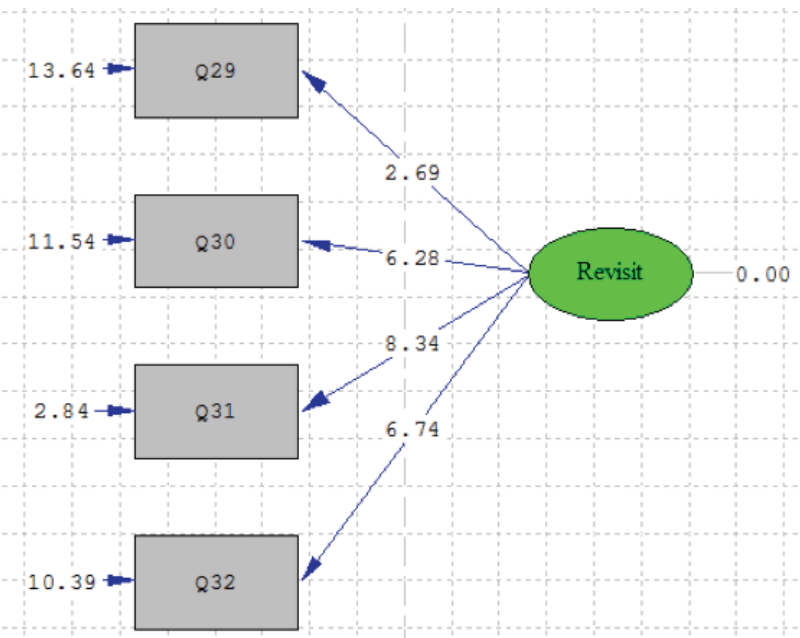

Figure 14: Meaningfulness of relationships of questions regarding intention to revisit

The chi-square value to the degree of freedom is lower than 3 for all the variables. The root mean square error of approximation (RMSEA) is equal to or lower than 0.08. In the following sections, standard values and meaningfulness of each research variable are given:

Table 3 shows that the factor analysis of components of the questionnaire has enough closeness and that these components appropriately illustrate the variables. 
Table 3: Results of factor analysis

\begin{tabular}{|c|c|c|c|c|c|}
\hline Variables & Factor loading & T-Value & Variables & Factor loading & T-Value \\
\hline \multicolumn{3}{|c|}{ Destination awareness } & \multicolumn{3}{|c|}{ Brand loyalty } \\
\hline 1 & 0.42 & 7.37 & 18 & 0.52 & 9.88 \\
\hline 2 & 0.69 & 12.91 & 19 & 0.65 & 12.62 \\
\hline 3 & 0.65 & 11.97 & 20 & 0.70 & 13.88 \\
\hline 4 & 0.50 & 8.97 & 21 & 0.59 & 11.28 \\
\hline 5 & 0.48 & 8.55 & 22 & 0.57 & 10.95 \\
\hline 6 & 0.57 & 10.34 & 23 & 0.68 & 13.34 \\
\hline \multicolumn{3}{|c|}{ Brand image } & \multicolumn{3}{|c|}{ Brand equity } \\
\hline 7 & 0.39 & 6.96 & 14 & 0.69 & 12.92 \\
\hline 8 & 0.69 & 11.98 & 15 & 0.52 & 9.47 \\
\hline 9 & 0.86 & 14.31 & 16 & 0.62 & 11.55 \\
\hline 10 & 0.41 & 7.42 & 17 & 0.72 & 13.45 \\
\hline \multicolumn{3}{|c|}{ Satisfaction } & \multicolumn{3}{|c|}{ Intention to revisit } \\
\hline 24 & 0.53 & 9.36 & 29 & 0.17 & 2.69 \\
\hline 25 & 0.58 & 10.28 & 30 & 0.42 & 6.28 \\
\hline \multirow[t]{2}{*}{26} & 0.48 & 8.40 & 31 & 0.79 & 8.34 \\
\hline & & & 32 & 0.48 & 6.74 \\
\hline \multirow[t]{2}{*}{27} & 0.62 & 11.16 & \multicolumn{3}{|c|}{ Brand quality } \\
\hline & & & 11 & 0.35 & 5.35 \\
\hline \multirow[t]{2}{*}{28} & 0.65 & 11.71 & 12 & 0.76 & 7.32 \\
\hline & & & 13 & 0.54 & 6.59 \\
\hline
\end{tabular}

\subsection{Equation Modeling of Research Model}

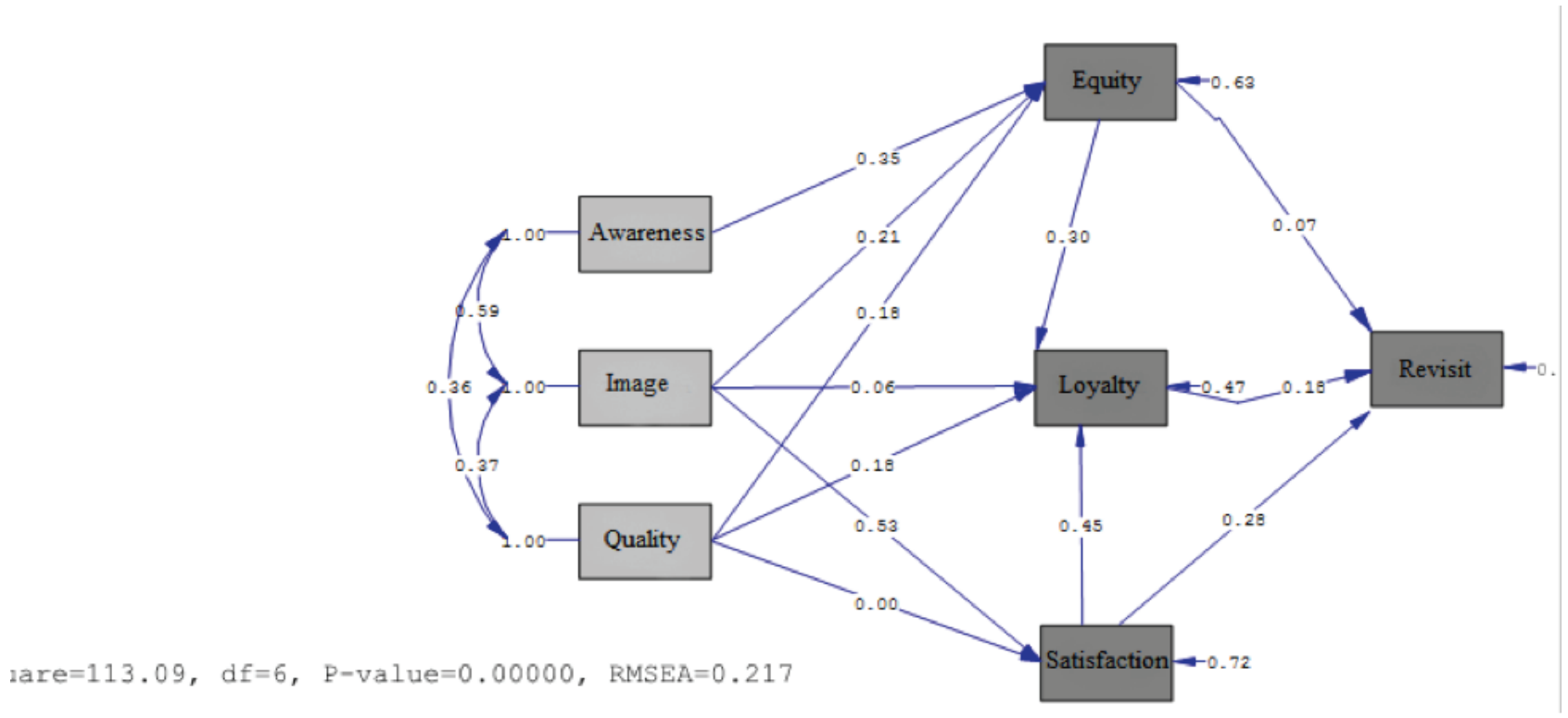

Figure 15: Finalised research model 
Other values of the finalised model are given in the fol-

lowing table:

Table 4: Values of the finalised model

\begin{tabular}{|c|c|c|c|c|c|c|c|}
\hline $\begin{array}{l}\text { The relationships of the } \\
\text { variables }\end{array}$ & $\begin{array}{l}\text { Estimated } \\
\text { value }\end{array}$ & $\begin{array}{l}\text { Standardised } \\
\text { value }\end{array}$ & Standard error & T-Statistic & $\begin{array}{l}\text { Specified } \\
\text { variance (R2) }\end{array}$ & Meaningfulness & $\begin{array}{l}\text { Testing } \\
\text { result }\end{array}$ \\
\hline $\begin{array}{l}\text { 1. Destination brand awareness } \\
\text { will positively and meaningfully } \\
\text { affect brand equity. }\end{array}$ & 0.12 & 0.35 & 0.017 & 6.79 & 0.37 & $P<0.01$ & Supported \\
\hline $\begin{array}{l}\text { 2. Brand image will positively } \\
\text { and meaningfully affect brand } \\
\text { equity. }\end{array}$ & 0.21 & 0.21 & 0.052 & 4.10 & 0.37 & $P<0.01$ & Supported \\
\hline $\begin{array}{l}\text { 3. Brand quality will positively } \\
\text { and meaningfully affect brand } \\
\text { equity. }\end{array}$ & 0.18 & 0.18 & 0.045 & 4.08 & 0.37 & $P<0.01$ & Supported \\
\hline $\begin{array}{l}\text { 4. Brand image will positively } \\
\text { and meaningfully affect brand } \\
\text { loyalty. }\end{array}$ & 0.20 & 0.06 & 0.16 & 1.25 & 0.53 & $P>0.05$ & $\begin{array}{l}\text { Not } \\
\text { supported }\end{array}$ \\
\hline $\begin{array}{l}\text { 5. Brand quality will positively } \\
\text { and meaningfully affect brand } \\
\text { loyalty. }\end{array}$ & 0.62 & 0.18 & 0.13 & 4.65 & 0.53 & $P<0.01$ & Supported \\
\hline $\begin{array}{l}\text { 6. Brand image will positively } \\
\text { and meaningfully affect } \\
\text { satisfaction. }\end{array}$ & 1.53 & 0.53 & 0.13 & 11.41 & 0.28 & $P<0.01$ & Supported \\
\hline $\begin{array}{l}\text { 7. Brand quality will positively } \\
\text { and meaningfully affect } \\
\text { satisfaction. }\end{array}$ & 0.01 & 0.00 & 0.13 & 0.08 & 0.28 & $P>0.05$ & $\begin{array}{l}\text { Not } \\
\text { supported }\end{array}$ \\
\hline $\begin{array}{l}\text { 8. Brand equity will positively } \\
\text { and meaningfully affect brand } \\
\text { loyalty. }\end{array}$ & 1.03 & 0.30 & 0.024 & 7.26 & 0.53 & $\mathrm{P}<0.01$ & Supported \\
\hline $\begin{array}{l}\text { 9. Satisfaction will positively } \\
\text { and meaningfully affect brand } \\
\text { loyalty. }\end{array}$ & 0.53 & 0.45 & 0.049 & 10.80 & 0.53 & $P<0.01$ & Supported \\
\hline $\begin{array}{l}\text { 10. Brand equity will positively } \\
\text { and meaningfully affect the } \\
\text { intention to revisit. }\end{array}$ & 0.07 & 0.07 & 0.053 & 1.38 & 0.20 & $P>0.05$ & $\begin{array}{l}\text { Not } \\
\text { supported }\end{array}$ \\
\hline $\begin{array}{l}\text { 11. Brand loyalty will positively } \\
\text { and meaningfully affect the } \\
\text { intention to revisit. }\end{array}$ & 0.05 & 0.18 & 0.019 & 2.86 & 0.20 & $P<0.05$ & Supported \\
\hline $\begin{array}{l}\text { 12. Satisfaction will positively } \\
\text { and meaningfully affect the } \\
\text { intention to revisit. }\end{array}$ & 0.10 & 0.28 & 0.02 & 4.88 & 0.20 & $P<0.01$ & Supported \\
\hline
\end{tabular}

\subsection{Closeness and Research Model}

The observed variance-covariance matrix or estimated variance-covariance matrix should have close values; in other words, they should have closeness. The more matrix values are close to each other, the higher will be model 
Table 5: Testing of Model Closeness

\begin{tabular}{llll}
\hline Indicator & Acceptable range & Value & Testing result \\
\hline $\mathrm{X}^{2} / \mathrm{d} f$ & $\mathrm{X} / \mathrm{d} f \leq 3$ & 2.84 & Supported \\
$\mathrm{RMSEA}$ & $\mathrm{RMSEA}<0.09$ & 0.00 & Supported \\
$\mathrm{GF}^{11}$ & $\mathrm{GFI}>0.9$ & 0.92 & Supported \\
$\mathrm{CFI}^{2}$ & $\mathrm{CFl}>0.90$ & 0.90 & Supported \\
$\mathrm{IFI}^{3}$ & $\mathrm{IFI}>0.90$ & 0.90 & Supported \\
$\mathrm{RFI}^{4}$ & $\mathrm{NFI}>0.90$ & 0.91 & Supported \\
\hline
\end{tabular}

1 Goodness of fit index

2 Comperation fit index

3 Inceremental fit index

4 Relative fit Index

closeness. In structural equation modelling, we can trust the estimates of the model only when it has enough closeness.

\section{Results}

The main purpose of this study was to examine tourists' assessments of destination brand equity. To this end, Kish Island was selected to be used as the case study.

According to findings of the study, hypothesis 1, i.e. destination brand awareness will positively and meaningfully affect brand equity, was supported. This is in line with findings of Boo, Busser and Baloglu (2009), Pike (2009), and Konecnik and Gartner (2007).

According to findings of the study, hypothesis 2, i.e. brand image will positively and meaningfully affect brand equity, was supported. This is similar to findings of Boo, Busser and Baloglu (2009), Pike (2009), and Konecnik and Gartner (2007).

According to findings of the study, hypothesis 3, i.e. brand quality will positively and meaningfully affect brand equity, was supported. This is similar to findings of Boo, Busser and Baloglu (2009), Pike (2009), and Konecnik and Gartner (2007).

According to findings of the study, hypothesis 4, i.e. brand image will positively and meaningfully affect brand loyalty, was not supported. The findings of this study are similar to those of Boo, Busser and Baloglu (2009), Pike (2009), and Konecnik and Gartner (2007).

According to findings of the study, hypothesis 5, i.e. brand quality will positively and meaningfully affect brand loyalty, was supported. This is in line with findings of Boo, Busser and Baloglu (2009), Pike (2009), and Konecnik and Gartner (2007).
According to findings of the study, hypothesis 6, i.e. brand image will positively and meaningfully affect satisfaction, was supported. This is in line with findings of Boo, Busser and Baloglu (2009), Pike (2009), and Konecnik and Gartner (2007).

According to findings of the study, hypothesis 7, i.e. brand quality will positively and meaningfully affect satisfaction, was not supported. This is this is different from findings of Boo, Busser and Baloglu (2009), Pike (2009), and Konecnik and Gartner (2007).

According to findings of the study, hypothesis 8, i.e. brand equity will positively and meaningfully affect brand loyalty, was supported. This is similar to findings of Boo, Busser and Baloglu (2009), Pike (2009), and Konecnik and Gartner (2007).

According to findings of the study, hypothesis 9, i.e. satisfaction will positively and meaningfully affect brand loyalty, was supported. This is in line with findings of Boo, Busser and Baloglu (2009), Pike (2009), and Konecnik and Gartner (2007).

According to findings of the study, hypothesis 10, i.e. brand equity will positively and meaningfully affect the intention to revisit, was not supported. This is different from findings of Boo, Busser and Baloglu (2009), Pike (2009), Konecnik and Gartner (2007), and Sibdari (2011).

According to findings of the study, hypothesis 11, i.e. brand loyalty will positively and meaningfully affect the intention to revisit, was supported. This is similar to findings of Boo, Busser and Baloglu (2009), Pike (2009), and Konecnik and Gartner (2007).

According to findings of the study, hypothesis 11, i.e. satisfaction will positively and meaningfully affect the intention to revisit, was supported. This is consistent with findings of Boo, Busser and Baloglu (2009), Pike (2009), Konecnik and Gartner (2007), and Sibdari (2011). 


\section{Recommendations}

Following the findings of the study, in this section, some operational recommendations are provided in detail.

1. Developing advertising campaigns to raise tourists' awareness: as it was shown in the analysis of the findings, brand awareness affects brand equity to a rather great extent. Correspondingly, the variable of destination brand awareness has a favorable situation, but it seems that effective advertisement can raise the awareness about Kish Island. Therefore, it is recommended that advertisements be put in shorter time limits and in higher quantities so as to be internalised in the minds of tourists. As for foreign visitors, international advertising is needed to raise foreign tourists' awareness of Kish Island attractions. It is preferable to advertise the island in a country in which tourism industry is active.

2. Using picture advertisements instead of information-giving activities as a way of raising tourists' awareness of Kish Island: it was pointed out that brand image affects brand equity. In this way, tourists first notice a picture advertisement of Kish Island and this picture will be internalised in their minds. As a consequence, imagined suitability of Kish Island increases in tourists' mind, leading them to treat its prices as reasonable and choose it as their destination.

3. Pressing the monitoring of service quality in places where tourists reside: based on the results of the study, brand quality affects both brand loyalty and brand equity. In tourists' viewpoints, this kind of quality includes such factors like easy transportation, quality of hotels, food and the ways it is served, personnel behavior and safety. Hence, due to the fact that brand quality has a significant effect on brand loyalty, quality deserves more attention. On the other hand, pressing the monitoring of service quality increases customers' loyalty and their intentions to revisit. Furthermore, perceived value of Kish Island leads tourists to revisit it. It is to be noted that this value is not perceived by non-visitors, but tourists' intentions to recommend it to others results in the increased brand equity and image. This will, in turn, lead to the attraction of potential visitors.

It is recommended that future studies focus on the comparative analysis of two or more than two destinations in order to provide a comparative analysis of customer-based brand equity. In addition, since tourism is treated as a kind of service delivery and a brand model has been applied to it, it is possible to do the same for other utilities so as to increase the quality of such services.

\section{References}

[1] Aaker, D. (2010). Strategic market management. Translated by Ahmad Roosta, Tehran: Aryana Ghalam Publication

[2] Ayubbi Y., H., \& Imani Kh., M. H. (2010). Factors affecting destination brand equity of Yazd. Quarterly of Tourism Studies, 13, 113-137

[3] Kline, P. (2001). An easy guide to factor analysis. Translated by Sadrossadat, J., \& Minai, A. Tehran: Samt Publication

[4] Movahed, A., Amanpour, S., \& Naderi, K. (2011). Marketing of city tourism based on branding with AHP model: A case study of Kermanshah. Scientific Journal of Spatial Planning, 1(3).

[5] Aaker, D. A., \& Joachimsthaler, E. (2000). Brand Leadership, London, Free Press

[6] Usakli, A., \& Baloglu, S. (2010). Brand personality of tourist destinations: An application of self- congruity theory. Tourism Management, 114-127

[7] Ambler, T., Bhattacharya, C. B., Edell, J., Keller, K. L., Lemon, K. L., \& Mittal, V. (2002). Relating brand and customer perspectives on marketing management. Journal of Service Research, 5(1), 13-25

[8] Baker, M. J., \& E. Cameron. (2008). Critical success factors in destination Marketing. Tourism and Hospitality Research 8(2), 79-95

[9] Bigne, J. E., Sanchez, I., \& Andreu, L. (2009). The role of variety seeking in short and long run revisit intentions in holiday destinations. International Journal of Culture, Tourism and Hospitality Research, 3(2), 103-115

[10] Blain, C., Levy, S. E., \& Ritchie, R. B. (2005). Destination branding: insights and practices from destination management organizations. Journal of Travel Research, 43, 328-338

[11] Boo, S. (2009). Multidimensional model of Destination brands: An application of customer-based brand equity, 5, 1-180

[12] Castro, C.B., Armario, E.M., \& Ruiz, D.M. (2007). The influence of market heterogeneity on the relationship between a destination's image and tourists' future behavior. Tourism Management, 28, 175-187

[13] Chen C. -F., \& Chen F. S. (2010). Experience Quality, Perceived Value, Satisfaction and Behavioral Intentions for Heritage Tourists., Tour. Manage., 31(1), 29-35

[14] Chen, C. -F., \& Tsai, D.(2007). How destination image and evaluate factors affect behavioral intentions?. Tourism Management, 28, 1115-1122

[15] Chen, C., \& Myagmarsuren, M. (2010). Exploring relationships between Mongolian destination brand equity, satisfaction and destination loyalty. Tourism Economics , 17, 981-994

[16] Geng-Qing, C. C., \& Qub, H. (2007). Examining the structural relationships of destination image, tourist. Tourism Management , 19, 624-636

[17] Cretu, A. E., \& Brodie, R. J. (2007). The influence of brand image and company reputation where manufacturers market to small firms: a customer value perspective. Industrial Marketing Management, 36(2), 230-240

[18] Gallagher, D., Ting, L., \& Palmer, A. (2008). A Journey into the Unknown: Taking the Fear out of Structural Equation Modeling with AMOS for the First-Timer User. The Marketing Review, 8(3), 255-275 
[19] Ghodeswar, B. M. (2008). Building brand identity in competitive markets: a conceptual model. Journal of Product \& Brand Management, 17 (1), 4-12

[20] Assaker, G., Vinzi, V. E., \& O'Connor, P. (2010). Examining the effect of novelty seeking, satisfaction, and destination image. Tourism Management, 13, 890-901

[21] Hall, D. (2002). Brand development, tourism and national identity; the re-imaging of former Yugoslavia. Brand Management, 9(4/5), 323-334

[22] Hsu et al., Hsu, C. H. C., Kang, S. K., \& Lam, T. (2006). Reference group influences among Chinese travelers. Journal of Travel Research, 44, 474-485

[23] Jang, S. C., \& Feng, R. (2007). Temporal Destination Revisit Intention: The Effects of Novelty Seeking and Satisfaction. Tourism Manage., 28(2), 580-590

[24] Garcia, M. G., \& Molina A. (2011). A destination-branding model: An empirical analysis based on stakeholders. Tourism Management, 35, 646-661

[25] Kayaman, R., \& Arasli, H. (2007), Customer based brand equity: evidence from the hotel industry. Managing Service Quality, 17, 92-109

[26] Konecnik, M., \& Gartner, W. C. (2007). Customer-based brand equity for a destination. Annals of Tourism Research, 34(2), 400-421
[27] Kumar, V., Smart, P. A., Maddern, H., \& Maull, R. S. (2008). Alternative Perspectives on Service Quality and Customer Satisfaction: The Role of BPM. International Journal of Service Industry Management, 19(2), 176-187

[28] Lee, J., \& Back, K. (2008). Attendee-based brand equity. Tourism Management, 29(2), 331-344

[29] Lim, Y. M. (2009). Customer-based brand equity: The Effect of Destination Image on Preference for Products Associated with a Destination Brand

[30] Lin, C.-H., Morais, D. B., Kerstetter, D. L., \& Hou, J.-S. (2007). Examining the Role of Cognitive and Affective Image in Predicting Choice Across Natural, Developed, and Theme-Park Destinations, Journal of Travel Research, 46(2), 183

[31] Pike, S. (2009). Destination brand positions of a competitive set of near-home destinations.Tourism Management, 30(6), 857-866

[32] Tasci, A. D. A., Gartner, W. C., \& Cavusgil, S. T. (2007). Measurement of destination brand bias using a quasiexperimental design. Tourism Management, 28(6), 1529-1540

[33] Zeithaml, V. A. (2012). Consumer perception of price, quality, \& value: a means-end model $\&$ synthesis of evidence. Journal of Marketing, 52(3), 2-22

[34] Zins, A.H. (2013). Relative attitudes and commitment in customer loyalty models. International Journal of Service Industry Management, 21, 269-294 